\title{
ELECTROCHEMICAL PROCESSING OF USED NUCLEAR FUEL
}

\author{
K. M. GOFF, J. C. WASS, K. C. MARSDEN, and G. M. TESKE \\ Idaho National Laboratory \\ Idaho Falls, Idaho USA \\ *Corresponding author. E-mail : mike.goff@inl.gov
}

Received August 14, 2011

As part of the Department of Energy's Fuel Cycle Research and Development Program an electrochemical technology employing molten salts is being developed for recycle of metallic fast reactor fuel and treatment of light water reactor oxide fuel to produce a feed for fast reactors. This technology has been deployed for treatment of used fuel from the Experimental Breeder Reactor II (EBR-II) in the Fuel Conditioning Facility, located at the Materials and Fuel Complex of Idaho National Laboratory. This process is based on dry (non-aqueous) technologies that have been developed and demonstrated since the 1960s. These technologies offer potential advantages compared to traditional aqueous separations including: compactness, resistance to radiation effects, criticality control benefits, compatibility with advanced fuel types, and ability to produce low purity products. This paper will summarize the status of electrochemical development and demonstration activities with used nuclear fuel, including preparation of associated high-level waste forms.

KEYWORDS : Electrochemical, Pyrochemical, Pyroprocess, and Electrometallurgical

\section{INTRODUCTION}

The Fuel Cycle Research and Development Program within the U.S. Department of Energy's Office of Nuclear Energy is focused on development and assessment of sustainable nuclear fuel cycles for management of used nuclear fuel. Sustainable fuel cycles are those that improve uranium resource utilization, maximize energy generation, minimize waste generation, improve safety, protect the environment, limit proliferation risk, and are economically viable. An electrochemical process is one of the key technologies being developed as part of this program for recycle of metallic fast reactor fuel and treatment of light water oxide fuel to produce a feed for fast reactors.

Electrochemical process development is largely based on the technology deployed for treatment of used Experimental Breeder Reactor II (EBR-II) fuel. Treatment of EBR-II fuel has been ongoing in the Fuel Conditioning Facility (FCF), located at the Materials and Fuel Complex (MFC) of Idaho National Laboratory (INL), since 1996. This electrochemical process is part of a class of dry (non-aqueous) technologies that have been developed and demonstrated since the 1960s.

Dry separation technologies are being developed and demonstrated in many countries including the United States, Korea, Japan, Russia, France, United Kingdom, Czech Republic, China, and India. Dry processes typically employ salts and/or metals as solvents, and they offer potential advantages compared to traditional aqueous separation technologies like PUREX. Solvents used in dry technologies typically are not affected by temperature or radiation damage, so relatively short-cooled fuel can be processed. Dry processes can handle large quantities of fissile material, since a hydrogeneous moderator is not present. These technologies are potentially more compact than aqueous technologies, so the option exists to codeploy separations facilities with reactor complexes to lessen shipment of used nuclear fuel and special nuclear material. The ability to recycle short-cooled fuel provides a significant reduction in the quantity of fissile material engaged in the fuel cycle and minimizes fuel storage requirements.

These processes also typically result in limited purification of transuranic elements, especially from the lanthanide fission products. This characteristic was initially considered a disadvantage, since incomplete separation meant that the recovered materials still had to be processed in shielded hot cells. ${ }^{1}$ However, with the increased focus on non-proliferation, this feature is now considered a potential benefit.

Dry technologies like electrochemical processing are well suited for recycle of fast reactor fuels. Fast reactor fuels generally have higher radiation fields due to increased burnups, so solvent radiation damage is a concern. Fast 
reactor fuels also have significantly higher fissile material concentrations than light water reactor fuels, so criticality control can be limiting for batch size and throughput.

In general, dry technologies are not suitable as separation technologies for recycle of fuel to thermal reactors because they do not remove enough of the fission products. These fission products act as neutron poisons in a thermal neutron spectrum reactor. However, these same fission products cause limited deleterious effects in a fast neutron spectrum reactor. Because of the focus on fast reactors in future reactor fleets, the dry separation technologies have been assessed or used for many of the fuel types considered for advanced reactor technologies including metals, nitrides, and oxides.

\section{PROCESS DESCRIPTION}

Electrochemical processing has been deployed for the treatment of EBR-II fuel since 1996. This work has focused on the conditioning the used fuel so that it can be disposed in a geological repository. EBR-II used both a driver fuel, that was typically a metallic alloy of highly-enriched uranium, and a blanket fuel, that was depleted uranium. ${ }^{2}$

The first step in treatment operations is chopping the used fuel and loading the segments into steel baskets. The steel baskets are transferred into an electrorefiner. In the electrorefiner, they serve as an anode. The electrorefiner contains a molten salt medium of $\mathrm{LiCl}-\mathrm{KCl}$ eutectic and dissolved actinide chlorides, such as $\mathrm{UCl}_{3}$ and $\mathrm{PuCl}_{3}$.

In the electrorefiner, the used fuel is electrochemically dissolved from the anode baskets, and an equivalent amount of uranium is deposited on a steel cathode. The uranium is separated from the bulk of the fission products and transuranics. Most of the fission products (alkali, alkaline earth, rare earth, and halogens) and transuranics accumulate in the salt. The cathode products from electrorefining operations are further processed to distill adhering salt and to consolidate the dendritic uranium into a manageable form (Figure 1). The recovered uranium product is currently stored out of cell. Research is now being performed to determine if the enriched uranium can be recycled back to commercial light water reactors.

Electrochemical treatment of used fuel for disposition results in two high-level waste (HLW) forms, the ceramic waste form and the metal waste form. The ceramic waste form, which stabilizes electrorefiner salts, is a glassbonded sodalite produced from the thermal conversion of zeolite A. The salts are occluded into the zeolite structure in a heated V-mixer. After the salt is occluded into the zeolite structure, the salt-loaded zeolite is mixed with $25 \%$ glass frit. This mixture is loaded into a canister and then consolidated into a monolithic waste form in a furnace at $915^{\circ} \mathrm{C}$.

The metal waste form consists of metallic ingots that are used to stabilize noble metal fission products, cladding, and non-actinide fuel matrix materials. Zirconium metal is added to improve performance properties and to produce a lower melting point alloy. The typical composition is stainless steel with 15 weight percent zirconium. It is produced in a casting operation at $1600^{\circ} \mathrm{C}$.

When used fuel is treated for disposition, the transuranic elements, including plutonium, americium, neptunium and curium, are disposed in the ceramic waste. However, when the technology is applied for the recycle of used fuel, these elements must be recovered from the electrorefiner salts to produce the necessary feedstock for new fuel. To accomplish group recovery of the transuranic species, a liquid-cadmium cathode (Figure 2) has been employed. In this process, all the transuranic elements along with some uranium are recovered in a cadmium cathode. Because of the chemical similarity of the rare earth fission products and the transuranics, a portion of the rare earths is also recovered with the transuranics. The cadmium is subsequently separated from the recovered materials by distillation.

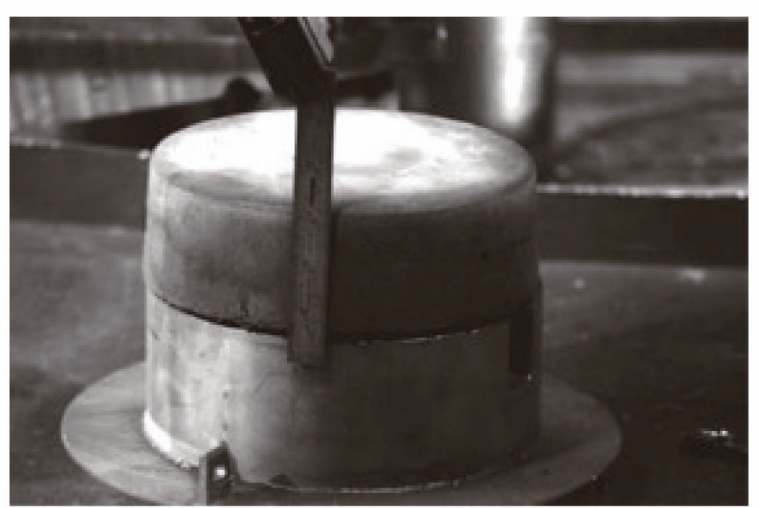

Fig. 1. Consolidated Uranium Recovered from Electrorefining.

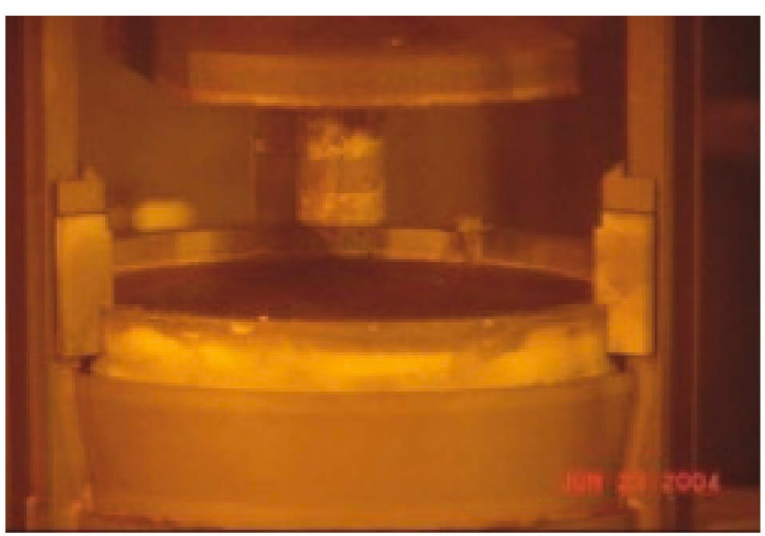

Fig. 2. Liquid-Cadmium Cathode for Group Recovery of Transuranic Elements. 
This transuranic product recovered from the liquid cadmium cathode has a substantial radiation field associated with it. As such, fabrication of fuel for recycle must be performed remotely in a hot cell. Such technology is well established. Injection casting has been used reliably since the 1960 s to remotely fabricate metallic fuel pins for recycle back to the EBR-II reactor. ${ }^{3}$

\section{FACILITIES}

As noted, electrochemical processing of EBR-II fuel is currently being conducted in shielded hot cell facilities at MFC at INL. The major facilities involved are the Fuel Conditioning Facility (FCF) and the Hot Fuel Examination Facility (HFEF). Support is also provided by hot cells, gloveboxes and specialized analytical equipment in the Analytical Chemistry Laboratory (ACL), which is also located at MFC.

FCF (Figure 3 ) is a large hazard category 2, safeguards category III/IV non-reactor nuclear facility that was built as the Fuel Cycle Facility in conjunction with EBR-II to demonstrate recycling of metal fuel using pyrometallurgical methods. FCF processed the first fuel from EBR-II in September 1964, and this continued until 1969, resulting in the production of almost 35,000 remotely fabricated metal fuel elements. Following this initial demonstration, FCF was used for post-irradiation examination of experimental fuel from EBR-II.

In the late 1980s and early 1990s, FCF was extensively upgraded to support metal fuel recycling as a part of the Integral Fast Reactor (IFR) program, which also utilized EBR-II to qualify a uranium-plutonium-zirconium alloy fuel. The upgrades included addition of a new emergency exhaust system for the argon cell, seismic upgrades of the facility structure, and significant improvements to the incell overhead handling systems and contaminated equipment maintenance areas. The IFR program was cancelled in 1994 and the remote fuel fabrication equipment that had been installed was removed. However, the used fuel processing equipment remained in place and is currently being used for electrochemical treatment of used EBR-II and other sodium-bonded metal fuel.

FCF consists of two hot cells, one having an air atmosphere and the other having an inert argon gas atmosphere. Both have 1.5-m thick high density concrete walls. The rectangular air cell, which has nine workstations, is $4.6-\mathrm{m}$ wide by $14.3-\mathrm{m}$ long by $6.4-\mathrm{m}$ high and is used for handling, storage, and disassembly of components. Each workstation is equipped with a leaded glass window, and six are also equipped with tele-manipulators.

The argon cell is an annular shape equivalent to a single linear cell $4.9-\mathrm{m}$ wide by $44.8-\mathrm{m}$ long by $6.7-\mathrm{m}$ high and has an argon gas atmosphere. It is used for processing oxygen or moisture reactive materials; oxygen and moisture concentrations are maintained at about $60 \mathrm{ppm}$ using a purification system. There are fifteen workstations in the argon cell and each is equipped with a leaded glass window and tele-manipulators. Each hot cell workstation is also equipped with electrical and pneumatic feedthroughs. These feedthroughs are modifiable or replaceable and can be changed to match the changing mission of the station. The FCF argon cell is equipped with two material transfer penetrations connected to the air cell, a large equipment transfer lock and a smaller vacuum lock used for most material transfers. The argon cell is serviced by four electro-mechanical manipulators (EMMs) rated for $340 \mathrm{~kg}$ and two 4.5-MT bridge cranes. Two EMMs and two cranes of similar capacity service the air cell. There are two pneumatic transfer stations inside the aircell, one

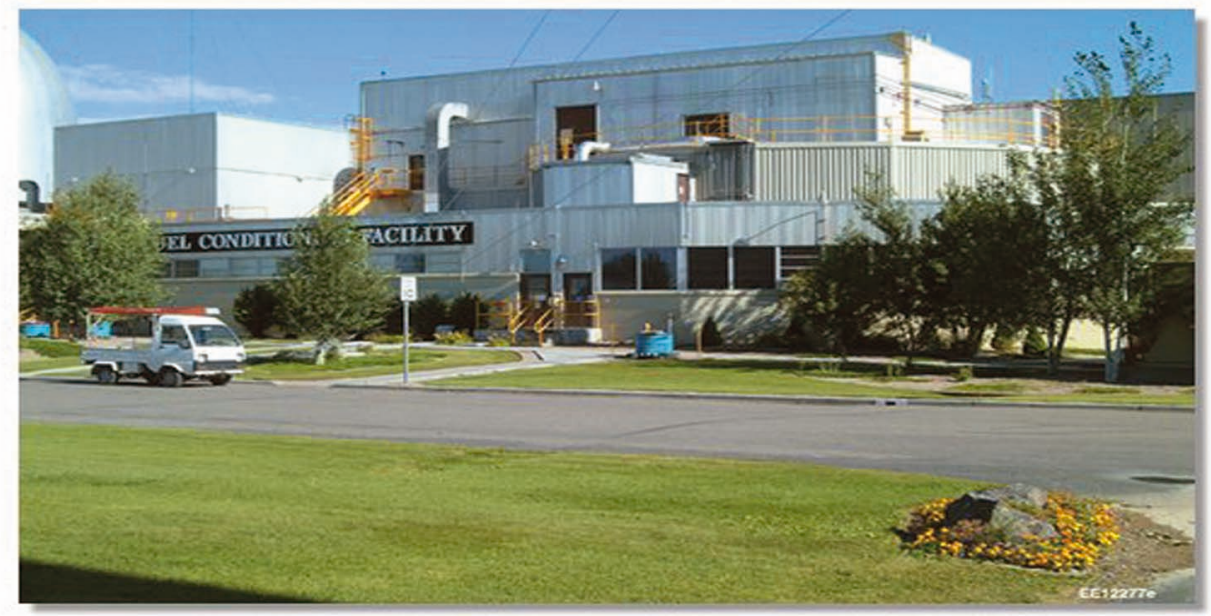

Fig. 3. Fuel Conditioning Facility. 
of which runs to HFEF and the other to the ACL. An enclosed passageway and cask tunnel connects FCF and EBR-II and provided a means for transferring fuel between the reactor and the hot cell using a heavily shielded cask.

HFEF is another large hazard category 2, safeguards category III/IV non-reactor nuclear facility that was designed to remotely characterize highly irradiated fuel and structural materials. HFEF was activated in March 1975 , and most of its programs have centered on postirradiation examinations of fuels and materials irradiated in experimental and commercial reactors. Currently about half of the argon cell (Figure 4) available for programmatic missions is being used for electrochemical separations research and development and waste form production.

HFEF consists of two adjacent shielded hot cells similar in size and general configuration to FCF. The HFEF argon cell is $21.3-\mathrm{m}$ long by $9.1-\mathrm{m}$ wide by $7.6-\mathrm{m}$ high with 1.2-m thick high density concrete walls and has an argon gas atmosphere. The argon cell is equipped with six material transfer penetrations. The transfer penetrations include a large equipment vacuum lock, a small equipment lock, a floor penetration for access to shielded shipping casks, a ceiling penetration equipped with a purged lock for large experiment handling, and two rapid insertion tool locks. There is a pneumatic transfer station inside the argon cell that connects it to a shielded metallography box. A 2.4-m deep sub-floor cavity is located beneath removable flooring over the entire width of the east end of the cell, and this space is used for storage of materials and equipment.

The air cell is adjacent to and communicates with the west end of the argon cell. It is $9.1-\mathrm{m}$ wide by $6.1-\mathrm{m}$ long by $7.6-\mathrm{m}$ high with $1.2-\mathrm{m}$ thick shielding walls. There are six workstations in the cell and each is equipped with a window and tele-manipulators.
Both HFEF cells are equipped with EMMs and cranes similar to FCF, but with a 1.2-m larger height capacity. The argon cell is serviced by two EMMs and two bridge cranes and the air cell by one of each.

\section{STATUS AND ACCOMPLISHMENTS}

The initial treatment of EBR-II fuel was part of a threeyear demonstration of electrochemical technology performed from 1996 through 1999 under review of the National Research Council (NRC). At the end of the demonstration, three of the main findings or recommendations from the NRC were:

"Finding: The committee finds that ANL has met all of the criteria developed for judging the success of its electrometallurgical demonstration project.

Finding: The committee finds no technical barriers to the use of electrometallurgical technology to process the remainder of the EBR-II fuel."

"Recommendation: If DOE wants an additional option besides PUREX for treating uranium oxide spent nuclear fuel, it should consider continued development and implementation of the lithium reduction step as a headend process to EMT.",

After the successful demonstration, DOE prepared an environmental impact statement, independent cost assessment, and non-proliferation assessment. ${ }^{5,6,7}$ Based on the results of these assessments, DOE moved forward with application of the technology to the treatment of sodium-bonded used fuel in 2000. Worked has focused on treatment of the EBR-II sodium-bonded fuel, but there is also sodium-bonded fuel from tests performed in

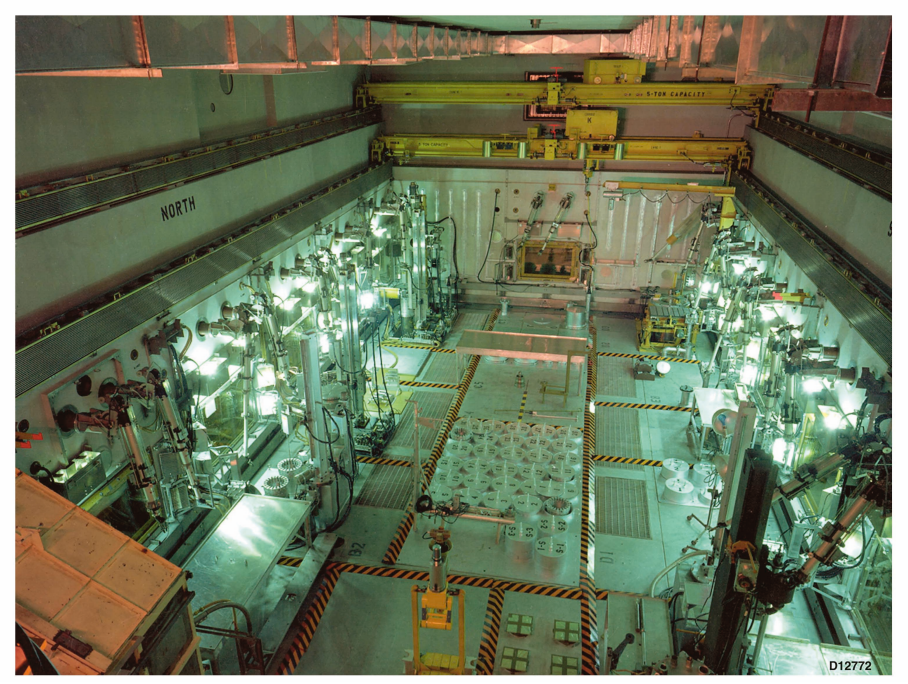

Fig. 4. Hot Fuel Examination Facility Argon Cell. 
the Fast Flux Test Facility (FFTF) at Hanford and from safety tests performed at Sandia National Laboratory (SNL). These were transferred to INL in 2008 (Figure 5), and treatment of FFTF fuel began in 2010 (Figure 6).

With the formation of the Advanced Fuel Cycle Initiate in 2002, application of electrochemical technology expanded beyond treatment to address recycle of fast reactor fuel. Research and development work included experiments with simulants, transuranics, and actual used nuclear fuel. Integral to this work are activities focused on development and implementation of process improvements and the qualification of resulting high-level waste forms. Research on electrochemical recycling has continued under DOE's Fuel Cycle Research and Development Program.

\subsection{Fuel Processing}

As described above, development and implementation of fuel processing technologies has been a major programmatic focus at INL. This section will describe the electrorefining equipment utilized for testing and will summarize key accomplishments in establishing performance data, demonstrating zirconium recovery, developing technologies for group actinide recovery, and assessing applicability of electrochemical treatment to other fuel types.

Development of fuel processing technologies has taken place in three different electrorefiners developed over the last 20 years. The first of these electrorefiners came online in HFEF in 1990. This laboratory scale unit, known as the Hot Fuel Dissolution Apparatus (HFDA), was used for initial feasibility testing with used fuel. It is sized for less than one kilogram of salt. The next two electrorefiners are closer to engineering-scale and have been employed for the treatment of used fuel in FCF. The first was installed in 1994 and the second in 1998. Both electrorefiners are one meter in diameter, and contain between 430 and $650 \mathrm{~kg}$

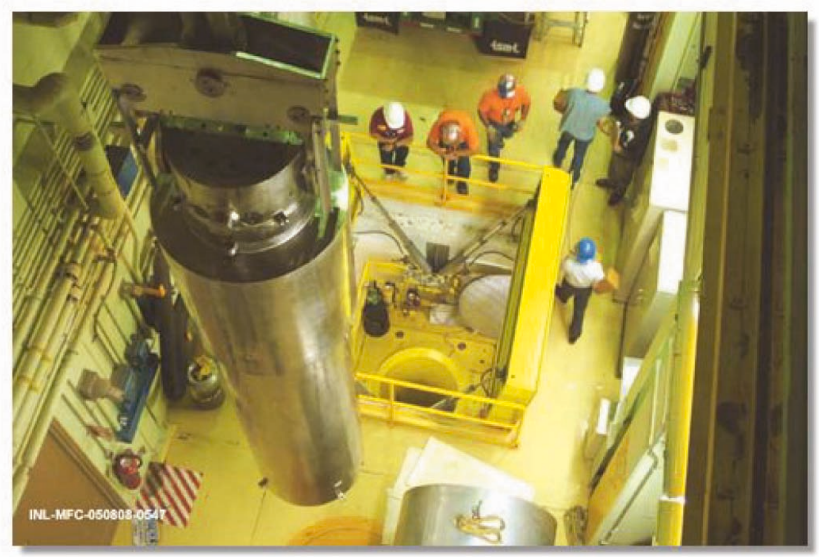

Fig. 5. Sodium-Bonded Material from SNL Transferred into HFEF. of molten salt. The base salt is high purity $\mathrm{LiCl}-\mathrm{KCl}$.

From the earliest tests with the HFDA to the more recent testing in the FCF units, the current capacities were increased from 3.5 to 2400 amps. Overall collection efficiencies have also improved, resulting in a three orders of magnitude increase in throughput.

The two FCF electrorefiners are identical in size. They differ in anode-cathode configuration and the presence or absence of a molten cadmium pool. A cadmium pool was placed in the first FCF electrorefiner, but was eliminated in the second design. Both electrorefiners have four ports in which electrodes are inserted into the molten salt. In the first of these electrorefiners, an individual anode or cathode is placed into each port, so two anode-cathode configurations can be operated simultaneously with two independent power supplies. For the second electrorefiner, the anode and cathode are combined into a concentric module. Four anode-cathode modules can be operated

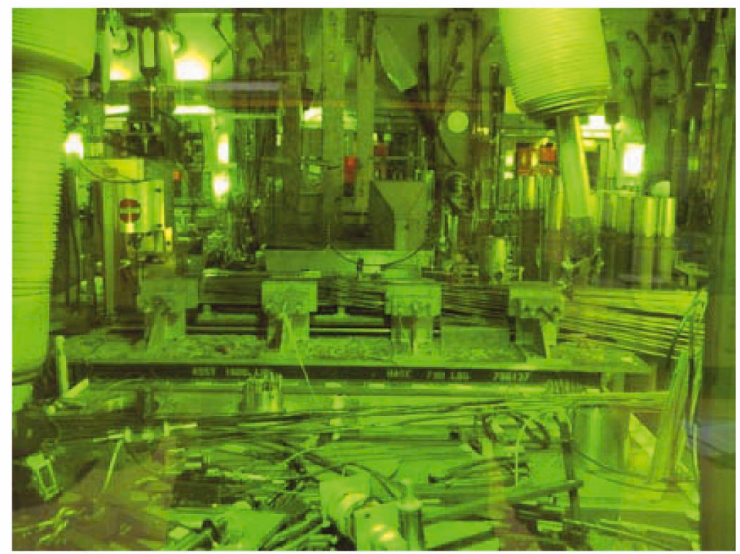

Fig. 6. FFTF Fuel Assembly Being Disassembled in HFEF.

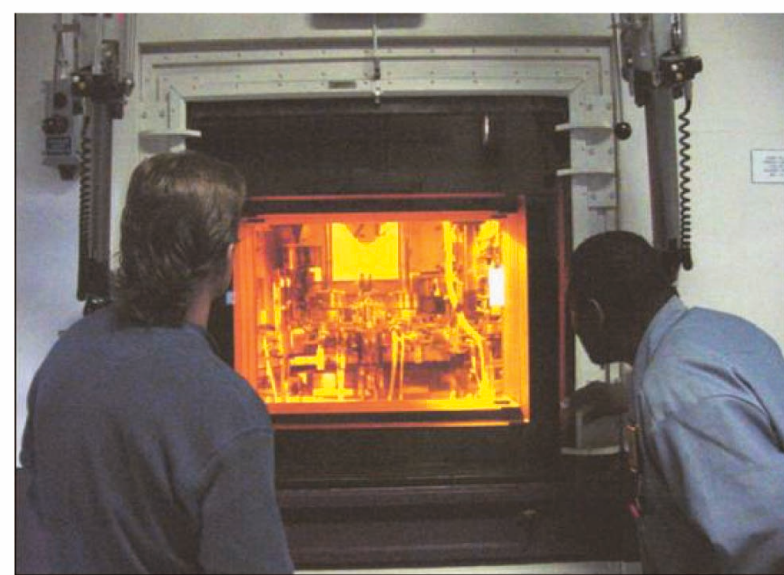

Fig. 7. Electrorefiner Viewed through Hot Cell Window in FCF Argon Cell. 
simultaneously in the second electrorefiner, and the capacity of each anode is twice that of the anode configuration for the first electrorefiner. Additionally, the current capacity of this design is approximately a factor of six higher. In total, the potential theoretical throughput increase between the first FCF electrorefiner and the later design is a factor of 20 in an identically sized vessel.

To date, more than 4.46 metric tons of heavy metal (MTHM), including both EBR-II driver fuel and blanket fuel, have been processed in these systems. 130 kilograms of heavy metal of FFTF fuel have also been processed. Because of the resistance of these salts to radiolysis effects, the same, relatively small volume of salt solvent has been used throughout these operations.

As electrorefiner technologies have improved, an increased emphasis was placed on establishing performance data with used fuel. One key performance aspect is dissolution of used fuel, specifically the actinides. Tests have been performed at laboratory scale with uranium-plutonium fuels and in FCF with uranium fuels. The results of both tests indicated the ability to dissolve at least $99.7 \%$ of the actinides. ${ }^{8}$ High dissolution of actinides results in significant positive benefits for geological disposal of resulting high-level wastes.

Tests have also been performed to demonstrate electrochemical recovery of zirconium. Some of the EBRII fuel is alloyed with $10 \mathrm{wt} \%$ zirconium, and advanced metallic fuels will likely use a zirconium alloy. Tests have been performed to demonstrate that zirconium rich cathodes can be recovered so the potential exists to recycle it with new fuel. Zirconium is also needed for the metal high-level waste; in this case zirconium is used to stabilize the cladding and noble metal fission products. Electrorefining experience has also demonstrated that zirconium can be left with the cladding materials to support waste operations.

Another key focus area for development of electrochemical treatment of used fuel is recovery of uranium and transuranics as a group. A group actinide recovery technology using a cathode of liquid cadmium was demonstrated at laboratoryscale in the HFDA and at the kilogram-scale in a FCF electrorefiner (Figure 8). ${ }^{9,10}$

Separation factor data obtained from testing indicate that the transuranics, including plutonium, are recovered together along with some of the rare earth fission products. The quantities of fission products recovered are at levels not expected to affect fuel performance in fast reactors.

Electrochemical technology with molten salts is also being assessed for treatment of non-metallic fuel types. Most commercial used nuclear fuel is oxide based. Laboratory-scale tests with used oxide fuels have been performed. To treat these fuel types, the oxides are first electrochemically reduced from oxides to metals. Oxygen gas is evolved in the process. The reduced metal is then processed using the flowsheet discussed earlier. Reduction occurs in a separate vessel from the uranium electrorefiners.

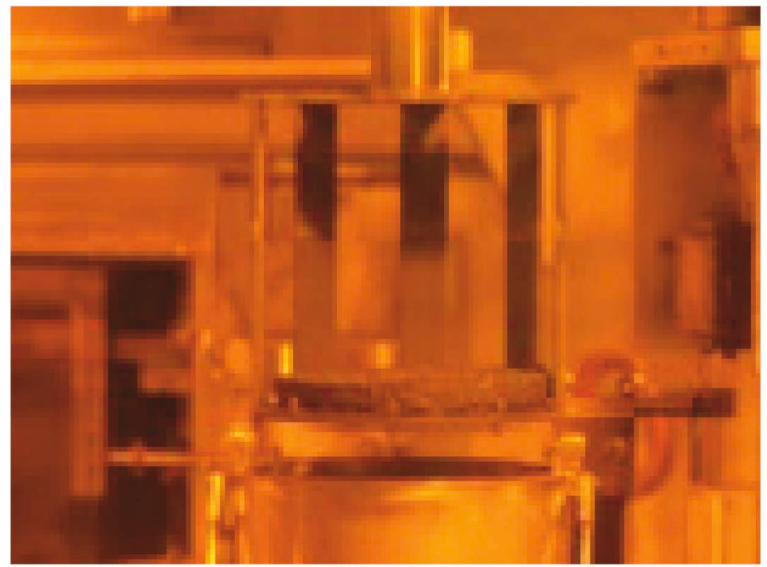

Fig. 8. Ingot from the Group Recovery of Actinides Using a Liquid-Cadmium Cathode

The base salt for oxide reduction is $\mathrm{LiCl}$ with $1 \mathrm{wt} \% \mathrm{Li}_{2} \mathrm{O}$, and the operating temperature is $650^{\circ} \mathrm{C}$.

Laboratory-scale tests with used oxide fuels have been performed. These laboratory-scale tests were completed with 50-gram loadings of irradiated oxide fuel. Reduction values as high as $99.7 \%$ have been obtained. ${ }^{11}$ Subsequent electrorefining of the reduced metal in a standard $\mathrm{LiCl}-$ $\mathrm{KCl}$ electrorefiner was also demonstrated.

\subsection{High-Level Waste Processing}

Demonstration and qualification of the two high-level wastes from electrochemical treatment were performed in parallel with development of the electrorefining processes. In each case, the waste forms were tailored to the process. Activities are underway to support both qualification of waste forms and qualification of production processes. Extensive characterization activities were performed on both waste forms, and degradation models were developed to simulate performance in a geological repository. Work performed on these waste forms demonstrates that they should be acceptable for disposal in a geological repository., ${ }^{42}$

High-level waste operations for electrochemical treatment of used nuclear fuel are performed in HFEF. A vacuum furnace (Figure 9) is used to separate adhering salt from used fuel cladding by distillation and then to melt the remaining metals into an ingot for disposal. It operates at $1600^{\circ} \mathrm{C}$. The furnace was installed in 2008 , and is expected to be on-line to process used EBR-II cladding in the fall of 2011.

A consolidation furnace for production of full-scale ceramic waste was procured, installed, and is ready for operation and process testing out of cell (Figure 10). Process testing will first be performed with waste form surrogates before installation in a hot cell. This furnace is capable of producing $400-\mathrm{kg}$ waste forms. Other equipment 


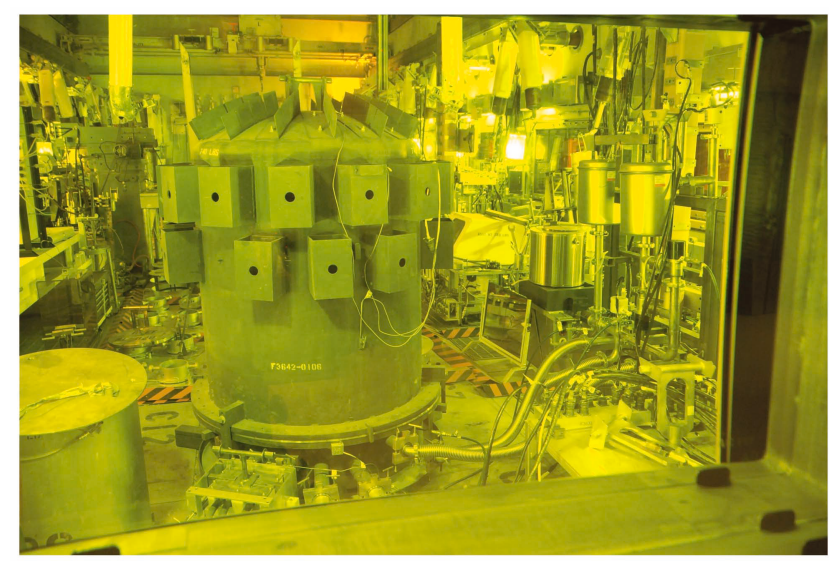

Fig. 9. Metal Waste Furnace in HFEF.

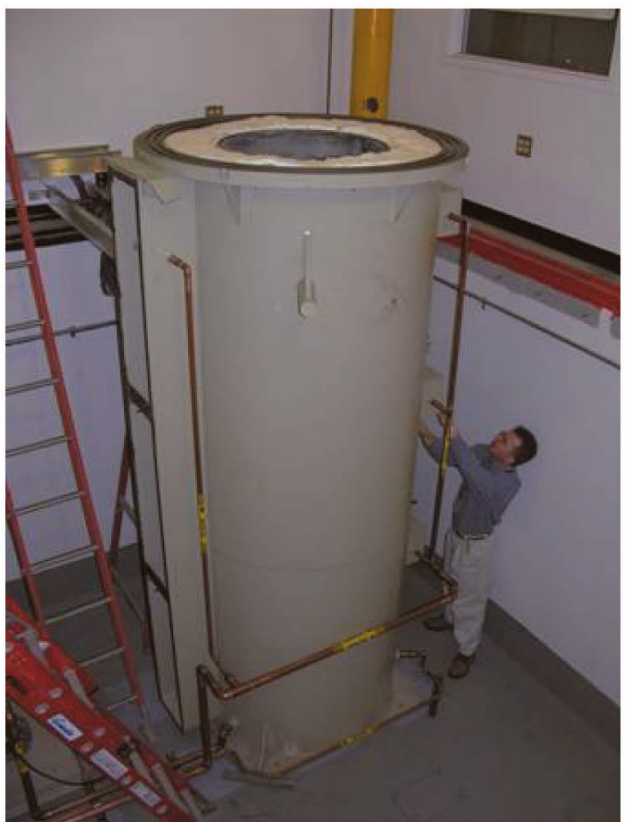

Fig. 10. Ceramic Waste Furnace

used for the production of the ceramic waste form, including a large heated V-mixer and a mill/classifier, are already installed and operational in HFEF.

\section{CONCLUSIONS}

Electrochemical processing has been developed and deployed for treatment of used EBR-II fuel. Significant advancements in this technology have been made in the past twenty years. Development testing and demonstration operations for aspects of the flowsheet have been performed with used fuel. During this period, electrorefining testing was scaled by three orders of magnitude in remote hot cells. Critical process goals such as high fuel dissolution were achieved. Work is currently underway to demonstrate additional key aspects of the technology, including both group recovery of transuranics and application of the technology to commercial oxide fuels. In parallel with work on fuel treatment processes, HLW production processes have been designed and are being qualified and implemented. This technology may provide benefits over conventional aqueous options for treating used nuclear fuel and may enable the deployment of the next generation of nuclear power systems.

\section{ACKNOWLEDGMENTS}

The Department of Energy's Office of Nuclear Energy is funding the research and development activities on electrochemical processing and treatment of EBR-II used fuel. Prior to formation of INL in February 2005, these activities were part of work scope at Argonne National Laboratory-West and were performed in collaboration with Argonne National Laboratory in Illinois. The Department of Energy's Office of Environmental Management is funding the treatment of FFTF used fuel.

\section{REFERENCES}

[ 1 ] Benedict, Pigford, and Levi. Nuclear Chemical Engineering (New York: McGraw-Hill Book Company, 1981).

[2] L. J. Koch, Experimental Breeder Reactor II: An Integrated Experimental Fast Reactor Nuclear Power Station (Argonne, IL: Argonne National Laboratory, 2004).

[ 3 ] C. E. Stevenson. The EBR-II Fuel Cycle Story (La Grange Park, IL: American Nuclear Society, 1987).

[4] National Research Council, "Electrometallurgical Techniques for DOE Spent Fuel Treatment: Final Report," National Academy Press, Washington, DC (2000).

[ 5 ] U. S. Department of Energy, "Final Environmental Impact Statement for the Treatment and Management of Sodium Bonded Spent Nuclear Fuel," DOE/EIS-0306 (July 2000).

[6] "Cost Study of Alternatives Presented in the Draft Environmental Impact Statement for the Treatment and Management of Sodium-bonded Spent Nuclear Fuel" (August 1999).

[ 7 ] U.S. Department of Energy, Office of Arms Control and Nonproliferation, "Nonproliferation Impacts Assessment for the Treatment and Management of Sodium-Bonded Spent Nuclear Fuel" (July 1999).

[ 8 ] S. X. Li, T. A. Johnson, B. R. Westphal, K. M. Goff, and R. W. Benedict, "Electrorefining Experience for Pyrochemical Reprocessing of Spent EBR-II Fuel," Proceedings of GLOBAL 2005, Tsukuba, Japan, October, (2005).

[9] S. X. Li, S. D. Herrmann, K. M. Goff, M. F. Simpson, and R. W. Benedict, "Actinide Recovery Experiments with Bench-Scale Liquid Cadmium Cathode in Real Fission Product-Laden Molten Salt," Nuclear Technology, Vol. 
165, No. 2, p. 190 (2009).

[10] D. Vaden, S. X. Li, B. R. Westphal, K. B. Davies, T. A. Johnson, and D. M. Pace, "Engineering Scale Liquid Cadmium Cathode Experiments," Nuclear Technology, Vol. 162, No. 2, pp. 124 (2008).

[11] S. D. Hermann, S. X. Li, M. F. Simpson, S. Phongikaroon, "Electrolytic Reduction of Spent Nuclear Oxide Fuel as
Part of an Integral Process to Separate and Recover Actinides from Fission Products," Separations Science and Technology, 41: 1965-1983, 2006.

[12] U. S. Department of Energy, Office of Nuclear Energy, Science and Technology, "A Report to Congress on Electrometallurgical Treatment Waste Forms," (March 2001). 